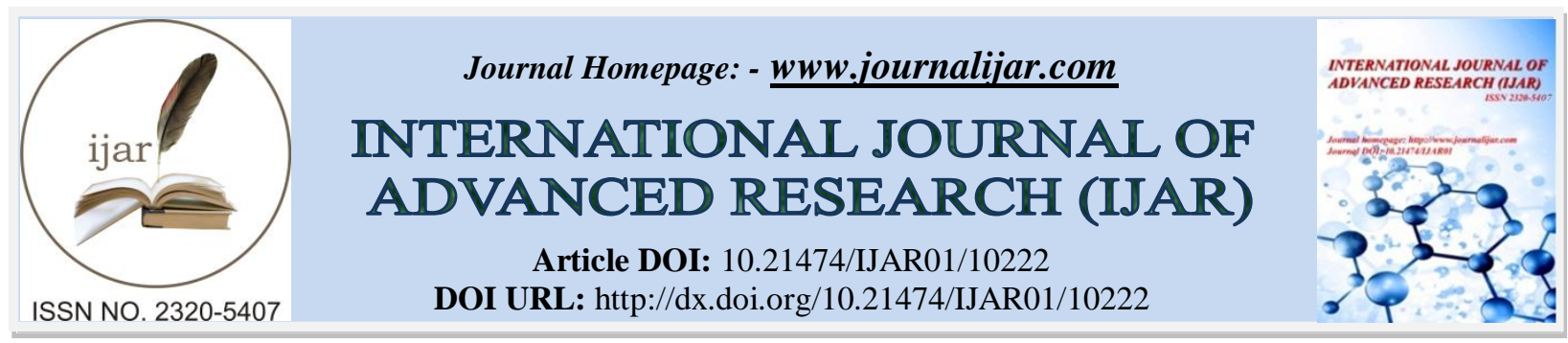

RESEARCH ARTICLE

\title{
NUTRACEUTICALS: A BETTER ALTERNATIVE TO STATINS IN THE FIGHT AGAINST ATHEROSCLEROSIS? - A REVIEW
}

\author{
Hari Priyaa G, Dr. Sinjitha S Nambiar and Dr. Sunil S. More \\ School of Basic and Applied Sciences, Dayananda Sagar University, Kumaraswamy Layout, Bangalore - 78, \\ Karnataka, India.
}

\section{Manuscript Info}

Manuscript History

Received: 10 October 2019

Final Accepted: 12 November 2019

Published: December 2019

Key words:-

Atherosclerosis, Nutraceuticals, Natural

Products, Molecular Pathway

\begin{abstract}
Atherosclerosis: A major cause of death in today's world- is an inflammatory disease resulting from high plasma concentrations of cholesterol, especially that of Low - density lipoprotein (LDL). It leads to formation of lipid laden plaques which later blocks coronary arteries leading to heart attacks. Current medications used for the treatment and prevention are statins. However, statins have dangerous neuronal side effects. Traditional System of medicine in India- Ayurveda lists medicines which also serve as food in our daily lives, hence the name Nutraceuticals: The knowledge of these Nutraceuticals is currently being integrated into therapeutic regimen, considering the serious side effects of allopathic drugs. Medicinal plants have wide range of antiatherosclerotic compounds many of which are as yet unexplored. Many of these plants have even shown reversal of atherosclerotic plaques. The present review provides a comparison of the action of Nutraceuticals with statins and shows how statins could one day be replaced with Nutraceuticals as the major therapy for atherosclerosis.
\end{abstract}

Copy Right, IJAR, 2019,. All rights reserved.

\section{Introduction: -}

Atherosclerosis is an inflammatory disease of the coronary arteries, leading to plaque formation which causes thinning of the arterial lumen ultimately leading to blockage of arteries and termination of blood supply to the heart resulting in heart attacks (1). Fatty streaks are formed by an interaction between lipoproteins circulating in the blood, cytokines, vascular smooth muscle cells, macrophages, in an environment of insulin resistance, hypertension and dyslipidemia (2). The plaque can also dislodge and move to other areas in arteries leading to stroke. Circulating oxidized LDLs are taken up by macrophages and these in turn get transformed to foam cells. The activation of macrophages by ox-LDL leads to the release of cytokines like interferon $\gamma$ (IFN- $\gamma$ ), interleukin-1 $\beta$ (IL-1- $\beta$ ), interleukin -6 (IL-6), tumor necrosis factor $\alpha$ (TNF- $\alpha$ ) which causes further Monocytes migration into the subendothelial space (3). In the subendothelial space, these monocytes differentiate into macrophages and start phagocytizing the lipids via scavenger receptors like lectin like oxidized LDL receptor (LOX-1), scavenger receptor A (SRA), CD36 and get converted to lipid-laden foam cells (1, 4-5). These foam cells thereupon become static and are unable to migrate which lead them to accumulate resulting in an inflammatory condition which sets the ground for plaque development. Sustained inflammation results in increased proliferation of macrophages and more inflammation leading to necrosis of foam cells. These dead cells accumulate and stimulate vascular smooth muscle cells to migrate from tunica media to tunica intima via inflammation. These cells form a layer and enclose the dead foam (lipid- laden macrophage) cells and form a capsule (plaque) within the arterial lumen reducing the diameter of

Corresponding Author: - Dr. Sinjitha S Nambiar.

Address:- School of Basic and Applied Sciences, Dayananda Sagar University, Kumaraswamy Layout, 858 
the lumen, thus decreasing the volume of blood flow to the heart. The fatty streak lesion later progresses to form complex lesions that cause stenosis to limit the blood flow to the heart. These complex lesions ultimately form the sites where thrombosis occurs leading to myocardial infarction (6).

\section{Mechanism Of Atherosclerosis: -}

The first cellular components in lesion formation are known as macrophages. ox-LDL through scavenger receptors taken up by macrophages, like scavenger receptors-A and CD36 that are not subjected to down regulation via a feedback mechanism like LDL receptor. Inflammatory response by the macrophages is caused by the uptake of ox-LDL by these scavenger receptors results in the secretion of cytokines. Macrophages continue the process of Ox-LDL uptake and accumulation of lipids from Ox-LDL resulting in the formation of lipid filled foam cell which constitute the premature cellular phase of lesions. Foam cells can also remove lipids from the sub-endothelial area through ATP-binding cassette transporters such as ABCA1, ABCG1 which in additional carried by high-density lipoprotein (HDL) to advance metabolism. The process of cholesterol deduction is decreased causing the macrophages to accumulate lipids continuously as the plaque advances, causing in the death of these cells followed by the release of intracellular molecules which leads to assiduous chronic inflammation (7).

The inflammation causes smooth muscle cells to migrate from the tunica media to tunica intima, multiply and rearranges in the extracellular matrix (8). This results in the formation of the fibrous atherosclerotic plaques. The resultant lesion is characterized by calcification (sclerosis), which makes artery wall firm and fraileventually leading to the rupture of the covering endothelium causing the formation of thrombus and intravascular coagulation.

\section{Effect Of Ox-Ldl On The Signal Transduction Pathway: -}

Ox-LDL activates epidermal growth factor receptor (EGFR) which then causes the phosphorylation and activation of Akt. Activated Akt phosphorylates and activates P38 MAP kinase (9) and also activates nuclear factor erythroid 2 related factor 2 (Nrf2) (10). Nrf2 activation leads to augmented expression of CD36 leading to increased ox-LDL uptake in macrophages and foam cell formation. Akt activation, in addition to activating P38 MAP kinase, also activates nuclear factor (NF)- $\kappa \mathrm{B}$ pathway which in turn leads to cytokine secretion thus enhancing inflammatory process. Emblica officinalis extracts have been shown to inhibit NF- $\kappa$ B activation in osteoclast cells (11). P38 activation in macrophages by ox-LDL also leads to multiplying (12). Migration Inhibition and apoptosis in future stages which ultimately plays a role in plaque formation (13). Henceforth this pathway is important for plaque development. Atherosclerotic plaque formation progresses with the proliferation, inhibition of migration, foam cell formation, followed by apoptosis of macrophages and resultant inflammation, inhibition of all these steps could highly decrease the development of the ailment.

\section{Nutraceuticals And Molecular Pathway: -}

Various plants and their Nutraceuticals have been found to reduce the formation of plaque by different mechanisms. Recent research has revealed many oral hypolipidaemic compounds from plant of ayurvedic reputation and many of these compounds showed potent anti-atherosclerotic activity. Allium sativum is one such plant rich in hypolipidemic compounds. It is extremely beneficial in counteracting many cardiovascular diseases by many mechanisms including reversal of atherosclerotic plaques (14). Allium sativum extracts have many chemical compounds. One such compound being allicin counters atherosclerosis by causing about cholesterol efflux in foam cells by upregulating efflux receptor like ABCA1, blocking many pathways involved in atherosclerosis like downregulating scavenging receptor like CD36, inhibiting NFKB etc. Reverse plaque in hypercholesterolemic rabbit models has been reported in E. officinalis fruit extract (15).

The extract of Agaricus blazei has been shown to prevent the activation of Akt and P38 by ox-LDL in macrophages. It prevents the development and buildup of foam cells and increase macrophages. Kaempferl is the compound has been shown to down regulate Akt activation in human glioma cells and has been found to be present in E. officinalis also. And it is also shown to reduce serum cholesterol levels in rats and reduction in NF- $\kappa \mathrm{B}$ activation and cycloxygenase (COX-2) expression (16). Hypercholesterolaemic rabbits fed with E. officinalis fruit extract for 4 months has been shown to bring about a reversal of dyslipidemia, intimal and medial thickening and plaque formation in the aorta of rabbits and also controls the lumen of the aorta to the level of the normal control group, the ability to prevent low-density lipoprotein oxidation and to lower cholesterol synthesis by inhibition of 3-hydroxy-3methylglutaryl-Coenzyme A reductase activity (15). It could also elevate high- density lipoprotein level and thus enhance reverse cholesterol transport. 
When there is no enough oxygen to the myocardium it causes angina in case of cardiovascular diseases (CVD's). different medicinal plants extracts are prescribed for the treatment of CVDs for example; Tinosporacardifolia (17), Allium sativum, Emblica officinalis, Withania sominfera, Crocus sativa, Saussurea costus and Salvia officinalis were traditionally used plants for healing heart diseases (18). Scutellaria strigillosa ethanol extract has a flavonoid which acts as the anti-proliferative and anti-migratory activities against vascular smooth mucle cells. The mechanism involved is the upregulation of SM22 $\alpha$ expression, henceforward inhibits ROS generation, and phosphorylation of ERK (19).

On the other hand, Atorvastatin and Fluvastatin, inhibit CD36, but also inhibit ABCA1 and hence inhibit cholesterol efflux (an undesirable side effect) (20,21). Thus, in contrast to the multitargeted approach of plant compounds, each of the statins target only one pathway and are wrought with treacherous side effects like memory loss, neuropathy, type 2 diabetes etc.

The below table 1 represents about the Nutraceuticals compounds acquiring efficient cardio-protective activity and table 2 describes about current therapies for atherosclerosis and their Shortcomings.

Table 1:- Nutraceuticals Compounds Acquiring Efficient Cardio-Protective Activity.

\begin{tabular}{|c|c|c|}
\hline Compound & Mechanism of action & Reference \\
\hline Rutin in Buckwheat & $\begin{array}{l}\text { 1. Inhibits ERK and AKT activation, } \\
\text { 2. Inhibits NF- } \mathrm{KB} \text { activation in inflammatory mice model } \\
\text { 3. CD36 downregulation, Upregulates ABCA1 in obese mice } \\
\text { model, inhibits proliferation and migration of VSMC }\end{array}$ & $(22-24)$ \\
\hline $\begin{array}{l}\text { Allicin and } \\
\text { s-allylcysteine in } \\
\text { Garlic }\end{array}$ & $\begin{array}{l}\text { 1. Suppress P38, } \\
\text { 2. CD36 downregulation, } \\
\text { 3. Inhibits NFkB activation, } \\
\text { 4. Upregulation of ABCA1 in macrophage derived foam cells } \\
\text { 5. Inhibits proliferation and migration of VSMC }\end{array}$ & $(25-27)$ \\
\hline $\begin{array}{l}\text { Garcinol in Garcinia } \\
\text { indica }\end{array}$ & $\begin{array}{l}\text { 1. Downregulates NF- } \mathrm{kB} \text {, Downregulates p42 MAP Kinase in rat } \\
\text { models } \\
\text { 2. Down regulates ERK in cancer cell lines } \\
\text { 3. Increased ABCA1 and ABCG1 in mice model } \\
\text { 4. Inhibits proliferation and migration of VSMC }\end{array}$ & $(28-30)$ \\
\hline
\end{tabular}

Table 2:- Current Therapies for Atherosclerosis and Their Shortcomings.

\begin{tabular}{|c|c|c|c|}
\hline Therapy & $\begin{array}{l}\text { Common } \\
\text { Drug }\end{array}$ & Mechanism & Side Effects \\
\hline \multirow{3}{*}{$\begin{array}{l}\text { Statins (lowers bad } \\
\text { cholestrol) } \\
\text { (Li., Chen and } \\
\text { Mehta., 2001) }\end{array}$} & $\begin{array}{l}\text { Atorvastatin } \\
\text { (Lipitor) }\end{array}$ & $\begin{array}{l}\text { 1. Inhibits ERK, } \\
\text { 2. Fails to regulate ABCA1(31) }\end{array}$ & \multirow{3}{*}{$\begin{array}{l}\text { Muscle pain, digestive problems } \\
\text { and mental fuzziness in some } \\
\text { people and causes liver damage }\end{array}$} \\
\hline & $\begin{array}{l}\text { Fluvastatin } \\
\text { (Lescol) }\end{array}$ & $\begin{array}{ll}\text { 1. } & \text { Promotes migration of VSMC } \\
\text { 2. } & \text { Suppresses ABCA1 } \\
\text { (Undesirable effect) } & (32-33)\end{array}$ & \\
\hline & $\begin{array}{l}\text { Simvastatin } \\
\text { (Zocor) }\end{array}$ & $\begin{array}{l}\text { 1. Upregulation of CD36 in } \\
\text { presence of ox-LDL } \\
\text { 2. Promotes migration of VSMC } \\
\text { in presence of ox-LDL }(17,34)\end{array}$ & \\
\hline Nicotinic acid & $\begin{array}{l}\text { Niacin } \\
\text { (Improve } \\
\text { Overall } \\
\text { Cholesterol) }\end{array}$ & $\begin{array}{l}\text { 1. Fails to activate ABCA1 } \\
\text { 2. Promotes migration of VSMC } \\
\text { (35) }\end{array}$ & $\begin{array}{l}\text { 1. Increase Blood sugar } \\
\text { levels, } \\
\text { uncomfortable Skin flu } \\
\text { shing }\end{array}$ \\
\hline
\end{tabular}

\section{Conclusion: -}

Atherosclerotic plaque not only causes myocardial infarction but also dislodges from coronary arteries, gets into different blood vessels and blocks these arteries causing stroke. Statins are beneficial in keeping the disease under control but do not reverse the plaque once formed. Plant extracts and their compounds have advantages over statins 
in that they target multiple pathways at the same time and are devoid of side effects. However, each type of statins (even though they prevent cholesterol formation) tend to upregulate scavenging receptors or downregulates efflux receptors which aggravates the disease and are wrought with plenty of dangerous side effects. Thus, considering the imperfect treatment approach of statins, plant compounds with their multi-dimensional treatment modes, without any side effects, may become the drug of choice for the common masses in the near future hence forth it can enter the phase of clinical trials.

\section{References: -}

1. Lusis A. Atherosclerosis (2000) Nature. 407: 233-241.

2. Haller H (1977) Epidermiology and associated risk factors of hyperlipoproteinemia. Zeitschrift fur die gesamteinnereMedizin und ihreGrenzgebiete32(8): 124-128.

3. Quinn MT, Parthasarathy S, Fong LG and Steinberg D (1987) Oxidatively modified low density lipoproteins: a potential role in recruitment and retention of monocyte/macrophages during atherogenesis. Proceedings of the National Academy of Sciences84(9): 2995-2998.

4. Steinberg D (1997) Low density lipoprotein oxidation and its pathobiological significance. J. Biol. Chem272(34): 20963-20966.

5. Skålén K, Gustafsson M, Rydberg EK, Hultén LM, Wiklund O, Innerarity TL and Borén J (2002) Subendothelial retention of atherogenic lipoproteins in early atherosclerosis. Nature417(6890): 750.

6. Cushing SD, Berliner JA, Valente AJ, Territo MC, Navab M, Parhami F, Gerrity R, Schwartz CJ and Fogelman AM (1990) Minimally modified low density lipoprotein induces monocyte chemotactic protein 1 in human endothelial cells and smooth muscle cells. Proceedings of the National Academy of Sciences87(13): 5134-5138.

7. Glass CK and Witztum JL (2001) Atherosclerosis: the road ahead. Cell104(4): 503-516

8. Libby P, Ridker PM and Maseri A (2002) Inflammation and atherosclerosis. Circulation105(9): 1135-1143.

9. Ríos PG, Kalra AA, Wilson JD, Tanji K, Akman HO, Gómez EA, Schon EA and DiMauro S (2012) Congenital megaconial myopathy due to a novel defect in the choline kinase Beta gene. Archives of neurology69(5): 657661 .

10. Xu X, Li H, Hou X, Li D, He S, Wan C, Yin P, Liu M, Liu F and Xu J (2015) Punicalagin induces Nrf2/HO-1 expression via upregulation of PI3K/AKT pathway and inhibits LPS-induced oxidative stress in RAW264. 7 macrophages. Mediators of inflammation

11. Penolazzi L, Lampronti I, Borgatti M, Khan MTH, Zennaro M, Piva R and Gambari R (2008) Induction of apoptosis of human primary osteoclasts treated with extracts from the medicinal plant Emblica officinalis. BMC complementary and Alternative Medicine8(1): 59

12. Senokuchi T, Matsumura T, Sakai M, Yano M, Taguchi T, Matsuo T, Sonoda K, Kukidome D, Imoto K, Nishikawa T and Kim-Mitsuyama S (2005) Statins suppress oxidized low density lipoprotein-induced macrophage proliferation by inactivation of the small G protein-p38 MAPK pathway. Journal of Biological Chemistry280(8): 6627-6633.

13. DeVries-Seimon T, Li Y, Yao PM, Stone E, Wang Y, Davis RJ, Flavell R and Tabas I (2005) Cholesterolinduced macrophage apoptosis requires ER stress pathways and engagement of the type A scavenger receptor. $\mathrm{J}$ Cell Biol. 171(1): 61-73.

14. Varshney R and Budoff MJ (2016) Garlic and heart disease. The Journal of nutrition146(2): 416S-421S.

15. Antony B, Merina B, Sheeba V and Mukkadan J (2006) Effect of standardized Amla extract on atherosclerosis and dyslipidemia. Indian journal of pharmaceutical sciences68(4).

16. Yokozawa T, Kim HY, Kim HJ, Tanaka T, Sugino H, Okubo T, Chu DC and Juneja LR (2007) Amla (Emblica officinalis Gaertn) attenuates age-related renal dysfunction by oxidative stress. J. of Agricultural and Food Chemistry55(19): 7744-7752.

17. Ruiz-Velasco N, Domínguez A and Vega MA (2004) Statins upregulate CD36 expression in human monocytes, an effect strengthened when combined with PPAR- $\gamma$ ligands Putative contribution of Rho GTPases in statininduced CD36 expression. Biochemical pharmacology67(2): 303-313.

18. Tirtha S.S., The Ayurveda Encyclopedia: Natural Secrets to Healing, Prevention and Longevity, Sat Yuga Press (2007).

19. Li J, Wang H, Shi X, Zhao L, Lv T, Yuan Q, Hao W and Zhu J (2019) Anti-proliferative and anti-migratory effects of Scutellaria strigillosa Hemsley extracts against vascular smooth muscle cells. Journal of ethnopharmacology235:155-163.

20. Sone H, Shimano H, Shu M, Nakakuki M, Takahashi A, Sakai M, Sakamoto Y, Yokoo T, Matsuzaka K, Okazaki H and Nakagawa Y (2004) Statins downregulate ATP-binding-cassette transporter A1 gene expression in macrophages. Biochemical and biophysical research communications316(3): 790-794. 
21. Li et al (2001) Statins inhibit oxidized-LDL-mediated LOX-1 expression, uptake of oxidized-LDL and reduction in $\mathrm{PKB}$ phosphorylation. Cardiovascular research.

22. Potapovich AI, Lulli D, Fidanza P, Kostyuk VA, De Luca C, Pastore S and Korkina LG (2011) Plant polyphenols differentially modulate inflammatory responses of human keratinocytes by interfering with activation of transcription factors $\mathrm{NF \kappa B}$ and $\mathrm{AhR}$ and EGFR-ERK pathway. Toxicology and Applied Pharmacology255(2): 138-149.

23. Gao M, Ma Y and Liu D (2013)Rutin suppresses palmitic acids-triggered inflammation in macrophages and blocks high fat diet-induced obesity and fatty liver in mice. Pharmaceutical research30(11): 2940-2950.

24. Karki R, Park CH and Kim DW (2013) Extract of buckwheat sprouts scavenges oxidation and inhibits proinflammatory mediators in lipopolysaccharide-stimulated macrophages (RAW264. 7). Journal of Integrative Medicine11(4): 246-252.

25. Li C, Lun W, Zhao X, Lei S, Guo Y, Ma J and Zhi F (2015) Allicin alleviates inflammation of trinitrobenzenesulfonic acid-induced rats and suppresses P38 and JNK pathways in Caco-2 cells. Mediators of inflammation.

26. Rahman K and Lowe GM (2006) Garlic and cardiovascular disease: a critical review. The Journal of nutrition136(3): 736S-740S.

27. Lin XL, Hu HJ, Liu YB, Hu XM, Fan XJ, Zou WW, Pan YQ, Zhou Q, Peng MW and Gu CH (2017) Allicin induces the upregulation of ABCA1 expression via PPAR $\gamma / \mathrm{LXR} \alpha$ signaling in THP-1 macrophage-derived foam cells. International journal of molecular medicine39(6):1452-1460.

28. LiaoCH, Sang S, Liang YC, Ho CT and Lin JK (2004) Suppression of inducible nitric oxide synthase and cyclooxygenase-2 in downregulating nuclear factor-kappa B pathway by Garcinol. Molecular Carcinogenesis: Published in cooperation with the University of Texas MD Anderson Cancer Center41(3): 140-149.

29. LiaoCH, Sang S, Ho CT and Lin JK (2005) Garcinol modulates tyrosine phosphorylation of FAK and subsequently induces apoptosis through down-regulation of Src, ERK, and Akt survival signaling in human colon cancer cells. Journal of cellular biochemistry96(1):155-169.

30. John OD, Brown L and Panchal SK (2019) Garcinia fruits: Their potential to combat metabolic syndrome. Nutraceuticals and Natural Product Derivatives: Disease Prevention \& Drug Discovery39-80.

31. Mandosi E, Fallarino M, Gatti A, Carnovale A, Rossetti M, Lococo E, Buchetti B, Filetti S, Lenti L and Morano S (2010) Atorvastatin downregulates monocyte CD36 expression, nuclear NFאB and TNF $\alpha$ levels in type 2 diabetes. Journal of atherosclerosis and thrombosis 1002040177.

32. Terblanche M, Almog Y, Rosenson RS, Smith TS and Hackam DG (2007) Statins and sepsis: multiple modifications at multiple levels. The Lancet infectious diseases7(5): 358-368.

33. Sassano A and Platanias LC (2008) Statins in tumor suppression. Cancer letters260(1-2): 11-19.

34. Ahn, Sethi and Aggarwal (2007) Simvastatin potentiates TNF- $\alpha$-induced apoptosis through the down-regulation of NF- $\kappa \mathrm{B}$-dependent antiapoptotic gene products.

35. Rubic T, Trottmann M and Lorenz RL (2004) Stimulation of CD36 and the key effector of reverse cholesterol transport ATP-binding cassette A1 in monocytoid cells by niacin. Biochemical pharmacology67(3): 411-419. 